\title{
Relationship Between Parents' Commitment to their Children's Education and Level of Students' Discipline in Public Secondary Schools in Naivasha Sub-County, Kenya.
}

\author{
Goodeve S.K Mwaniki, Dr. M. Ngunjiri, Prof. J. Kanjogu Kiumi
}

Department of Curriculum and Education Management, Laikipia University, Kenya.

\begin{abstract}
The purpose of this study was to assess the relationship between parents' commitment to their children'seducation and level of students' discipline in public secondary schools in Naivasha sub-county, Kenya. Thestudy targeted a total of 197 respondents (constituting 28 head teachers and 169 teachers). A total of 195respondents participated in the study (169 teachers and 26 principals) participated giving a response rate of $99 \%$. Purposive sampling technique was used to sample head teachers while Krejcie and Morgan's (1970)table for determining sample size for teachers. Questionnaires were used as instrument for data collection.SPSS was used to analyze the data where both descriptive and inferential statistics were used. The analyzeddata were presented in terms of graphs and tables. The results showed that there was a significant positiverelationship between parents' commitment to child's education and students' discipline $(\mathrm{r}=.387, \mathrm{p}=.000)$. Therefore, the null hypothesis that there was no significant relationship between parents' commitment tochild's education and students' discipline was rejected at .05 level of confidence. The study thereforeconcluded that parents' commitment to child's education influences students' discipline in secondaryschools in Naivasha sub-county. It was recommended that parents should be more committed to theirchildren's' education. This can be achieved through participating in school meetings and materiallysupporting the education of their children.
\end{abstract}

\section{Introduction}

Education has received unmatched attention as the best method of achieving a country's economic and social growth. It is the living bud of a nation's development (Muchemi, 2005). If a nation wishes to achieve any form of development, her people must be well socialized though a defined education system. It is through the education system that nations impart to their people the aspirations that will produce the citizens of their choice. The Kenyan government together with other stakeholders in education within and outside the country has invested heavily in education. Consequently, notable achievements have been realized in the country in regards to students' enrolment at all levels educations. For instance, at the secondary level of education, enrolment stood at 1,472,600 in 2009. In 2014, enrolment had increased to 2,331,700 representing a 58\% increase rate within a period of five years. There has also been an upward trend in Gross Enrolment Ratio (GER) and Net Enrolment Ratio (NER) in the Country at the secondary level of education. For instance, GER and NER at this level of education increased $16.4 \%$ and $14.3 \%$ respectively between 2009 and 2014 (MOEST, 2014).

The introduction of Free Primary Education (FPE) in 2003 resulted in increased enrolments in the primary schools and later in the subsequent secondary sub-sector. The period from 2003 therefore, has seen tremendous progress in the secondary sub-sector ranging from infrastructural and enrolment expansion to increased participation and transition rates (EMIS, 2008). For instance, there were a total of 5,019 public secondary schools in 2009. In 2014, there were a total of 7,686 secondary schools signifying an increase of 53\% (MOEST, 2014). This progress has been realized through the efforts of the government through initiatives like the Constituency Development Fund (CDF) and Local Authority Transfer Fund (LATF). 
Local communities and other Donor agencies have also helped in the expansion efforts of the educational institutions.

Education is widely valued across the world as a central factor in economic, political, and social development of any country (Republic of Kenya, 2012). The Constitution of Kenya (2010) articles 43.1f, $53.1 \mathrm{~b}$ and 55a makes education a right of every Kenyan while the Kenya Vision 2030 underscores the importance of education in ensuring relevant human and social capital for sustainable development. In particular, the Constitution guarantees every child to free and compulsory basic education. It further provides for access to affordable tertiary education, training and skills development. According to the Bill of Rights (2010), basic education is a fundamental human right. Despite the importance of basic education, there are a number of challenges facing its implementation and the realization of its goals. Among the challenges to the realization of the goals of secondary education is indiscipline among students. This is because students' discipline does not only provide a sense of dissention among learners and hence commitment to school values, but also has an influence on teachers' job satisfaction, motivation and consequently commitment to students and students learning (Imber \& Neidt, 1990). This observation has the implication that in a school environment where students' level of discipline is low, learning achievement may undoubtedly be compromised. In Naivasha Sub-County, where the study was executed, a total of 7 schools experienced unrest between 2010 and 2015 which translated to $25 \%$ of the total number of secondary schools in the Sub-County (Naivasha Sub-County Education Office, 2015).

Several studies have been carried out to determine the causes of students' indiscipline in schools. A majority of the studies have tended to show that unfavorable home and school based factors are critical antecedents to students' indiscipline. For example, Lockheed (1991) observed that an orderly school environment is closely linked with schools where teachers gain and hold the attention of their students, maintain discipline, begin and end lessons on time and evaluate student performance regularly. Muchemi (2006) observed that a school environment that is safe, peaceful and free from student riots should be the effort of all the school management fraternity.

Eshiwani (2001) asserted that students' strikes are a symptom of inability of the schools to cultivate relevant morals among the youth and this situation threatens socio-economic development of the nation. According to Masese (2007), the result of student strikes include incidences such as rape, violence, loss of school property, loss of lives and loss of school time due to frequent closures. This in turn leads to poor examination performances and also wastage of potential human resources due to expulsion of students who may be linked to such disturbances. From this premise, it is clear that discipline is essential to smooth functioning of schools and the society at large.

Etizi (2008) defines discipline as a system of making the individual to make reasonable decision responsibly. Etizi further says that the goal of discipline is to make it possible for the individual or a team of individuals to succeed in the set goals. The term therefore denotes the kind of order involved in the efforts by trying to reach appropriate standards to follow appropriate rules for engaging in a valid activity. It requires freedom of choice and makes one to understand the consequences and is not imposed by authority figures but rather individual themselves (Charles, 1995). Therefore, with discipline in our learning institutions, we would have very rare cases of the student strikes. Griffin (1994) asserts that sound discipline is an essential ingredient in the creation of a happy and industrious school community, performing properly its function of training the citizens of tomorrow. Based on this background, this study therefore sought to assess whether there is any relationship between parents commitment to children's education and discipline in schools.

\subsection{Statement of the Problem}

As it has been pointed out in the background part of the study, students' indiscipline in Kenyas' secondary schools is depicting a worrying trend. This is because; hardly a school term passes without incidents of indiscipline being reported in the mass media. This has the implication that if this behaviour trend goes unchecked, our secondary schools may not play their role expectations of producing responsible citizens. Evidence adduced from studies within and outside Kenya seems to suggest that unfavourable school and home environments are critical risk factors to students' misdemeanor. This study therefore assessed the 
relationship between parents' attitude towards children's education and level of students' discipline in public secondary schools in Naivasha sub-county, Kenya.

\section{Literature Review}

This section presents the theory used in the study and the relevant literature on the relationship between parents' commitment to their children's education and level of students' discipline and the theory used in the study.

\subsection{Theoretical Framework}

Rohner theory of socialization and Baumrid theory of parenting styles were used in this study. Rohner theory of Parental acceptance-rejection commonly known as a theory of socialization. This theory focuses on four major issues, i.e. behavioral, cognitive and emotional development of children and adult personality functioning. Every individual has experienced the warmth and affection provided to him/her by someone important, who is called the parent not necessarily, mother and father. This warmth and affection is a range from a great deal to none, where one end is parental acceptance while the other one is rejection (as cited in Hussain \& Munaf, 2012). Two dimensional model of parenting: warmth-hostility and restrictivenesspermissiveness was presented by Becker, high in warmth and restrictiveness Parents produce complaint, well-behaved children, whereas those high in warmth and permissiveness promote socially outgoing, independent, and creative children ( as cited in Khalid, 2004).

Baumrind (1966) theoretical model of parenting style which included the nurturance and control dimensions of child rearing into a conceptualization of parenting style that was fastened in an emphasis on parents' belief system (Darling \& Steinberg, 1993). For Baumrind, key element of parental role is to socialize the child to conform to the necessary demands of others and maintaining a sense of personal integrity. She defined control as strictness, use of corporal punishment, consistency of punishment, use of explanations, and so on (Baumrind, 1966). In contrast, Baumrind argued that parents' willingness to socialize their child is conceptually separate from parental restrictiveness. Rohner theory of socialization and Baumrid theory of parenting styles were used in this study to explain the influence of parents' commitment to child's education on discipline in schools.

\subsection{Parental Commitment to Children's Education and School in General}

Larocque, Kleiman, and Darling (2011: 116) describe parental involvement as family involvement, defining it as "parents' or caregivers' investment in the education of their children". Another way of defining this term would be "the ways that parents support their children's educational experiences and academic achievement" (Suizzo, et al., 2012: 534). Being involved in their children's education can be embodied in a number of ways and on multiple levels. Some parents are highly involved at the school level, i.e. volunteering in the classroom or school, chaperoning field trips or events, and communicating regularly with the teacher. Others may be involved more at the home level rather than the school level, helping with homework or providing time set aside each day for their child to do their homework, but not volunteering or communicating frequently with the school and its staff.

Quilliams and Beran (2009) found that the more parents are involved in the school and actively promote learning at home, the higher the student's grades. In the same study, when children's perceptions were considered, those who perceived that their parents had positive attitudes towards education and took interest in the school had higher achievement. In a study focusing on early elementary students and how different levels of parental involvement affected achievement, it was found that quality of instruction at the home, involvement in school, and parental expectation (all from the mother) had a higher impact on children's achievement in third grade than the child's IQ, educational level of the mother, and the student's achievement history (Englund et al., 2004).

Parental commitment towards child's education has been found to influence students discipline. For instance, according to statistics of the National Center for Education in the United States (cited in Sirvani, 2007) parental activity and involvement decreases the older their children grow. As an example, in the years 1996 and $1999,86 \%$ of parents with children in primary schools in America had at least one meeting with their 
children's teacher, while only $50 \%$ of parents with children in secondary school had at least one meeting with the teacher. In 2002-2003, the Department of Educational National Center released another report on parental involvement in schools in the United States, for Education Statistics in America (cited in Sirvani, 2007). According to that report, more than $90 \%$ of parents with children from kindergarten through grade five participated in their children's education, compared with $75 \%$ of parents in middle school, but when it came to grade nine and ten, 59\% of parents were involved. However, only $53 \%$ of parents with students in grade eleven and grade twelve were involved with their child's education. Findings such as these appear to contrast with the importance of parental involvement, and how important both parents and students believe parental involvement to be. Therefore, in my view, it is crucial for schools to establish and maintain a good and positive relationship with parents. But not only that, it is also essential that the schools clarify for parents the importance for them to stay involved and participate in their children's education.

Studies have shown marked improvement in students' academic achievement when their parents are involved with their homework (Keith \& Keith, 1993). For instance, a study of third and fifth grade students was conducted in an urban school district in the United States in 2001 (Sanders \& Sheldon, 2009). After controlling for prior reading achievement, that study suggests that students who have teachers that more frequently involve families with learning activities at home gained higher in reading achievements from one year to the next, compared to students with teachers who less frequently involved the families.

Similarly, findings from a study that Sirvani (2007) carried out showed that students with involved parents reached higher mathematical achievement than other students. In this study parents were divided into two groups, a control group and an experimental group. Parents in the experimental group were asked to monitor their children's homework and twice a week they received statements on their child's homework and test grades. Parents in the control group did not receive statements on their children's progress, nor were they asked to specifically monitor their children's homework. This light parental involvement in the experimental group was enough to increase their child's achievement in mathematics, compared to their own achievements the year before and compared to the achievement of the control group.

A number of studies have been carried out with regard to youth rebellion to authority in the home, school and societal fronts. An example is Kabiru (2006) who emphasizes the need for parents to instill discipline in their children at the family level. He observes that parents contribute to children's indiscipline in many ways; by being bad role models and by avoiding parental responsibilities such as teaching their children good behaviour. This rebellion was manifested in the groups or gangs the youth formed to show solidarity in defying the school or societal expectations. The same kinds of groups were formed in schools causing problems in the discipline system of the school. In Kenya, as in many growing economies, youth indiscipline was on the increase.

Deepshika \& Bhanot (2011) in their study to assess family environment and its impact on their social emotional adjustment revealed that eight family environment factors, viz. cohesion, expressiveness conflict, acceptance and caring, independence, active-recreational orientation, organization and control together showed significant role in socio-emotional and educational adjustment of the adolescent girls. When schools believe that lax parental discipline explains a child's misbehavior, educators are less likely to consider alternative explanations for the misbehavior and the full range of interventions that could be implemented at school (Greene, 2011). Osher, Bear, Sprague \& Doyle (2010) stated that the three approaches viz. ecological approaches to classroom management, school wide positive behavioural supports and social and emotional learning improves school discipline practices and student behavior.

\section{Methodology}

This study was carried out in public secondary schools in Naivasha Sub-county of Nakuru County, Kenya. The Sub-County has 28 public secondary schools. Ex-post facto research design was used in the study. The target population for the study compromised head teachers and teachers of public secondary schools in Naivasha Sub-county. The population for the study was 314 subjects comprising 28 principals and 286 teachers. The study targeted a total of 197 respondents (constituting 28 head teachers and 169 teachers). A total of 195 respondents participated in the study (169 teachers and 26 principals) participated giving a 
response rate of $99 \%$. Principals were purposively selected for the study while teachers were sampled based on Krejcie and Morgan's (1970) table for determining sample size (n) from a given population (N). A total of 169 teachers (n) were sampled from a total population of 286 teachers $(\mathrm{N})$ in the study area. Data was collected through a self-administered questionnaire. Two sets of questionnaires, one for head teachers and the other for teachers were used to collect the data. The scoring in the questionnaire was done using a tick against the statement given in scale from definitely true, true, undecided and definitely not true. Primary data from the field were edited to minimize errors made by respondents. Coding was done to translate question responses into specific categories. The coded items were analyzed with the aid of a computer on SPSS. Normal scale data, specifically data on respondents and school characteristics were analyzed using frequency counts and percentages. Descriptive statistics such as frequencies and percentages were used while inferential statistics such as chi-square was used to test the relationships between the study variables.

\section{Findings of The Study}

This section presents the findings of the study on the relationship between parents' commitment to their children's education and level of students' discipline in public secondary school in Naivasha sub-county, Kenya.

\subsection{Level of Students' Indiscipline As Reported by Principals and Teachers}

To establish the level of students' indiscipline, teachers and principals were asked to indicate the level of students' indiscipline in their schools. The findings are as presented Figure 1.

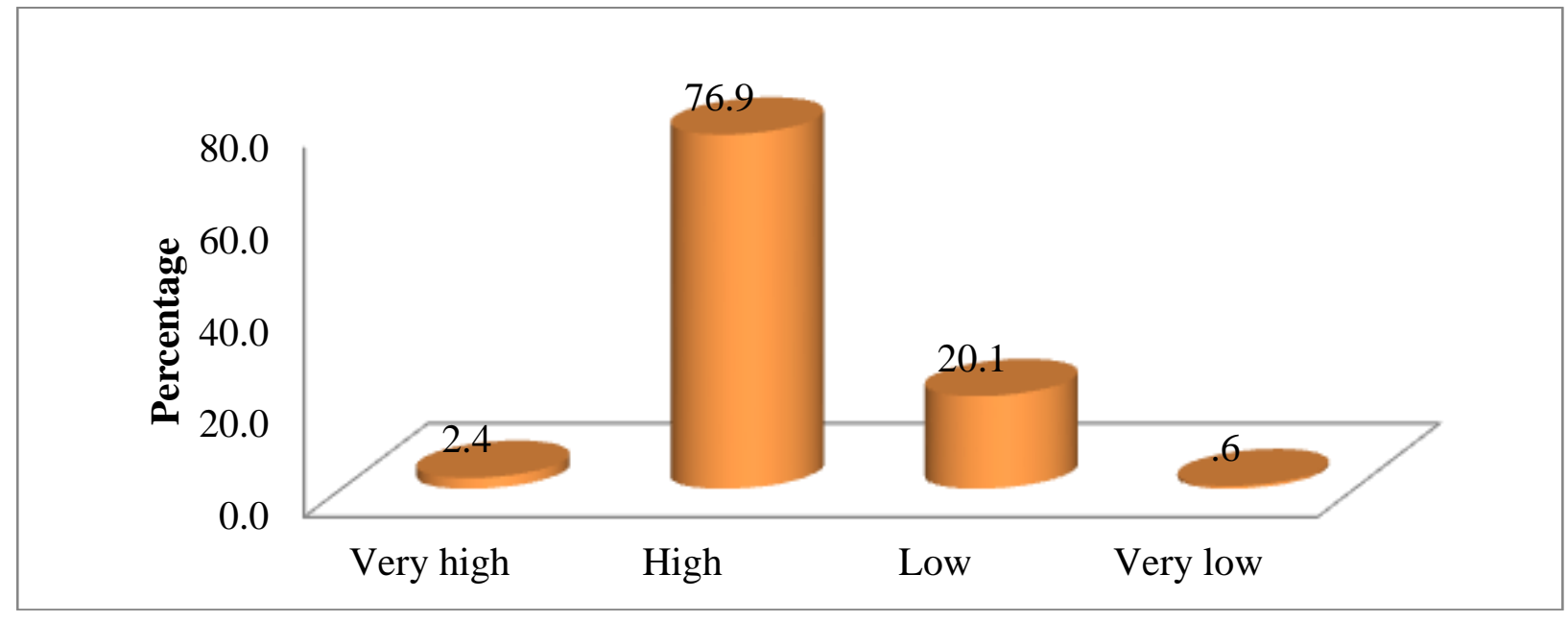

Source: Field Data (2017)

Figure 1: Level of Students' Indiscipline in Secondary Schools in Naivasha Sub-County

As is clearly shown in figure 1 , an overwhelming majority of teachers $(76.9 \%)$ reported that their students discipline was high. They were followed by $20.1 \%$ of teachers who indicated that students' level of discipline in their schools was low. Very few of the teacher respondents $(2.4 \%)$ reported that students' level of discipline in their schools was very high. Similarly, only $6 \%$ of the teacher respondents indicated that the level of students' discipline in their schools was very low.

\subsection{Parents' Commitment to Children's Education}

Responses to the Likert scale items on teachers' commitment to children's education were analyzed. This was accomplished by adding respondents' scores for each item and dividing by the number of respondents ( $\mathrm{n}=$ number of teachers). The mean scores are presented in Table 1 .

\section{Table 1: Parents' Commitment to Children's Education}

\begin{tabular}{|l|c|}
\hline Statement & Mean \\
\hline Failure by some parents to attend meetings arranged to discuss students' academic matters & 3.28 \\
\hline $\begin{array}{l}\text { Failure by some parents to respond positively when called by schools to discuss their children's } \\
\text { academic progress }\end{array}$ & 2.40
\end{tabular}




\begin{tabular}{|l|c|}
\hline Failure by some parents to supply their children with adequate prerequisite personal effects & 2.20 \\
\hline $\begin{array}{l}\text { Failure by some parents to willingly offer ideas to teachers on how to assist their children in the } \\
\text { academics }\end{array}$ & 2.15 \\
\hline Tendency by some parents to isolate themselves from teachers & 1.96 \\
\hline
\end{tabular}

Source: Field Data (2017)

A look at the data shown in table 1 demonstrates that the highest rated parents' commitment to children's education was failure by some parents to attend meetings arranged to discuss students' academic matters (mean 3.28). The findings also show average rating on failure by some parents to respond positively when called by schools to discuss their children's academic progress (mean 2.40), failure by some parents to supply their children with adequate prerequisite personal effects (2.20) and failure by some parents to willingly offer ideas to teachers on how to assist their children in the academics (mean 2.15). The least rated parents' commitment to students' education was tendency by some parents to isolate themselves from teachers (mean 1.96).

\subsection{Hypothesis test on Parents' Commitment to Children's Education and Students' Discipline}

The objective of the study was to investigate whether there is any statistically significant relationship between parents' commitment to child's education and students' discipline in public secondary school in Naivasha sub-county, Kenya. In order to achieve this objective, null hypothesis was formulated and stated as follows:

H01: There is no statistically significant relationship between parents' commitment to a child's education and students' discipline in public secondary schools in Naivasha sub-county, Kenya.

The findings, therefore, presumed that parents' commitment to child's education is not linked to students' discipline. To ascertain the truth of this preposition, the hypothesis was tested using data generated from likert scale findings as presented in Table 2 and tested using Pearson correlation coefficient in Table 3. 
Table 2: Parents' commitment to Child's Education and Students' discipline

\begin{tabular}{|c|c|c|c|c|c|c|c|c|c|c|c|c|c|c|c|c|c|}
\hline $\begin{array}{l}\text { Teache } \\
\text { rs }\end{array}$ & $\mathbf{Y}$ & $\mathbf{X}$ & $\begin{array}{l}\text { Teache } \\
\text { rs }\end{array}$ & $\mathbf{Y}$ & $\mathbf{X}$ & $\begin{array}{l}\text { Teache } \\
\text { rs }\end{array}$ & $\mathbf{Y}$ & $\mathbf{X}$ & $\begin{array}{l}\text { Teacher } \\
\text { s }\end{array}$ & $\mathbf{Y}$ & $\mathbf{X}$ & $\begin{array}{l}\text { Teacher } \\
\mathrm{S}\end{array}$ & $\mathbf{Y}$ & $\mathbf{X}$ & $\begin{array}{l}\text { Teacher } \\
\text { s }\end{array}$ & $\mathbf{Y}$ & $\mathbf{X}$ \\
\hline 1 & $\begin{array}{l}1 \\
7\end{array}$ & $\begin{array}{l}5 \\
6\end{array}$ & $\begin{array}{l}3 \\
0\end{array}$ & 8 & $\begin{array}{l}4 \\
8\end{array}$ & $\begin{array}{l}5 \\
9\end{array}$ & $\begin{array}{l}1 \\
7\end{array}$ & $\begin{array}{l}5 \\
6\end{array}$ & $\begin{array}{l}8 \\
8\end{array}$ & $\begin{array}{l}1 \\
0\end{array}$ & $\begin{array}{l}4 \\
7\end{array}$ & \begin{tabular}{l|}
1 \\
1 \\
7
\end{tabular} & $\begin{array}{l}1 \\
5\end{array}$ & $\begin{array}{l}5 \\
5\end{array}$ & $\begin{array}{l}1 \\
4 \\
6\end{array}$ & $\begin{array}{l}1 \\
5\end{array}$ & $\begin{array}{l}2 \\
0\end{array}$ \\
\hline 2 & $\begin{array}{l}1 \\
7\end{array}$ & $\begin{array}{l}5 \\
6\end{array}$ & $\begin{array}{l}3 \\
1\end{array}$ & 8 & $\begin{array}{l}5 \\
2\end{array}$ & $\begin{array}{l}6 \\
0\end{array}$ & 8 & $\begin{array}{l}5 \\
1\end{array}$ & $\begin{array}{l}8 \\
9\end{array}$ & $\begin{array}{l}1 \\
6\end{array}$ & $\begin{array}{l}4 \\
4\end{array}$ & $\begin{array}{l}1 \\
1 \\
8\end{array}$ & $\begin{array}{l}1 \\
7\end{array}$ & $\begin{array}{l}5 \\
6\end{array}$ & $\begin{array}{l}1 \\
4 \\
7\end{array}$ & $\begin{array}{l}1 \\
6\end{array}$ & $\begin{array}{l}5 \\
5\end{array}$ \\
\hline 3 & $\begin{array}{l}1 \\
7\end{array}$ & $\begin{array}{l}5 \\
6\end{array}$ & $\begin{array}{l}3 \\
2\end{array}$ & 8 & $\begin{array}{l}5 \\
1\end{array}$ & $\begin{array}{l}6 \\
1\end{array}$ & $\begin{array}{l}1 \\
8\end{array}$ & $\begin{array}{l}5 \\
6\end{array}$ & $\begin{array}{l}9 \\
0\end{array}$ & 7 & $\begin{array}{l}5 \\
1\end{array}$ & $\begin{array}{l}1 \\
1 \\
9\end{array}$ & $\begin{array}{l}1 \\
7\end{array}$ & $\begin{array}{l}5 \\
6\end{array}$ & $\begin{array}{l}1 \\
4 \\
8\end{array}$ & $\begin{array}{l}1 \\
6\end{array}$ & $\begin{array}{l}5 \\
7\end{array}$ \\
\hline 4 & $\begin{array}{l}1 \\
7\end{array}$ & $\begin{array}{l}5 \\
6\end{array}$ & $\begin{array}{l}3 \\
3\end{array}$ & 8 & $\begin{array}{l}5 \\
1\end{array}$ & $\begin{array}{l}6 \\
2\end{array}$ & $\begin{array}{l}1 \\
7\end{array}$ & $\begin{array}{l}5 \\
7\end{array}$ & $\begin{array}{l}9 \\
1\end{array}$ & $\begin{array}{l}1 \\
4\end{array}$ & $\begin{array}{l}5 \\
0\end{array}$ & $\begin{array}{l}1 \\
2 \\
0\end{array}$ & $\begin{array}{l}1 \\
7\end{array}$ & $\begin{array}{l}5 \\
6\end{array}$ & $\begin{array}{l}1 \\
4 \\
9\end{array}$ & $\begin{array}{l}1 \\
9\end{array}$ & $\begin{array}{l}5 \\
5\end{array}$ \\
\hline 5 & $\begin{array}{l}1 \\
8\end{array}$ & $\begin{array}{l}5 \\
7\end{array}$ & $\begin{array}{l}3 \\
4\end{array}$ & 8 & $\begin{array}{l}5 \\
1\end{array}$ & $\begin{array}{l}6 \\
3\end{array}$ & $\begin{array}{l}1 \\
7\end{array}$ & $\begin{array}{l}5 \\
6\end{array}$ & $\begin{array}{l}9 \\
2\end{array}$ & 6 & $\begin{array}{l}5 \\
6\end{array}$ & \begin{tabular}{l|}
1 \\
2 \\
1
\end{tabular} & $\begin{array}{l}1 \\
7\end{array}$ & $\begin{array}{l}5 \\
6\end{array}$ & $\begin{array}{l}1 \\
5 \\
0\end{array}$ & $\begin{array}{l}1 \\
9\end{array}$ & $\begin{array}{l}5 \\
5\end{array}$ \\
\hline 6 & $\begin{array}{l}1 \\
7\end{array}$ & $\begin{array}{l}4 \\
2\end{array}$ & $\begin{array}{l}3 \\
5\end{array}$ & 8 & $\begin{array}{l}5 \\
1\end{array}$ & $\begin{array}{l}6 \\
4\end{array}$ & 8 & $\begin{array}{l}5 \\
1\end{array}$ & $\begin{array}{l}9 \\
3\end{array}$ & $\begin{array}{l}1 \\
0\end{array}$ & $\begin{array}{l}4 \\
8\end{array}$ & \begin{tabular}{l|}
1 \\
2 \\
2
\end{tabular} & $\begin{array}{l}1 \\
8\end{array}$ & $\begin{array}{l}3 \\
0\end{array}$ & $\begin{array}{l}1 \\
5 \\
1\end{array}$ & $\begin{array}{l}1 \\
7\end{array}$ & $\begin{array}{l}5 \\
6\end{array}$ \\
\hline 7 & $\begin{array}{l}1 \\
8\end{array}$ & $\begin{array}{l}3 \\
0\end{array}$ & $\begin{array}{l}3 \\
6\end{array}$ & 8 & $\begin{array}{l}5 \\
1\end{array}$ & $\begin{array}{l}6 \\
5\end{array}$ & 8 & $\begin{array}{l}5 \\
1\end{array}$ & $\begin{array}{l}9 \\
4\end{array}$ & 8 & $\begin{array}{l}5 \\
1\end{array}$ & $\begin{array}{l}1 \\
2 \\
3\end{array}$ & $\begin{array}{l}1 \\
8\end{array}$ & $\begin{array}{l}3 \\
0\end{array}$ & $\begin{array}{l}1 \\
5 \\
2\end{array}$ & $\begin{array}{l}1 \\
7\end{array}$ & $\begin{array}{l}5 \\
6\end{array}$ \\
\hline 8 & $\begin{array}{l}1 \\
8\end{array}$ & $\begin{array}{l}3 \\
0\end{array}$ & $\begin{array}{l}3 \\
7\end{array}$ & 8 & $\begin{array}{l}5 \\
1\end{array}$ & $\begin{array}{l}6 \\
6\end{array}$ & 8 & $\begin{array}{l}5 \\
1\end{array}$ & $\begin{array}{l}9 \\
5\end{array}$ & $\begin{array}{l}1 \\
7\end{array}$ & $\begin{array}{l}5 \\
6\end{array}$ & $\begin{array}{l}1 \\
2 \\
4\end{array}$ & 8 & $\begin{array}{l}5 \\
1\end{array}$ & $\begin{array}{l}1 \\
5 \\
3\end{array}$ & 5 & $\begin{array}{l}5 \\
6\end{array}$ \\
\hline 9 & $\begin{array}{l}1 \\
8\end{array}$ & $\begin{array}{l}3 \\
0\end{array}$ & $\begin{array}{l}3 \\
8\end{array}$ & 8 & $\begin{array}{l}5 \\
1\end{array}$ & $\begin{array}{l}6 \\
7\end{array}$ & 8 & $\begin{array}{l}4 \\
8\end{array}$ & $\begin{array}{l}9 \\
6\end{array}$ & $\begin{array}{l}1 \\
4\end{array}$ & $\begin{array}{l}5 \\
3\end{array}$ & \begin{tabular}{l|}
1 \\
2 \\
5
\end{tabular} & 8 & $\begin{array}{l}5 \\
5\end{array}$ & $\begin{array}{l}1 \\
5 \\
4 \\
\end{array}$ & $\begin{array}{l}1 \\
5\end{array}$ & $\begin{array}{l}3 \\
0\end{array}$ \\
\hline $\begin{array}{l}1 \\
0\end{array}$ & $\begin{array}{l}1 \\
8\end{array}$ & $\begin{array}{l}3 \\
0\end{array}$ & $\begin{array}{l}3 \\
9\end{array}$ & 8 & $\begin{array}{l}5 \\
1\end{array}$ & $\begin{array}{l}6 \\
8\end{array}$ & 8 & $\begin{array}{l}5 \\
1\end{array}$ & $\begin{array}{l}9 \\
7\end{array}$ & $\begin{array}{l}1 \\
8\end{array}$ & $\begin{array}{l}5 \\
3\end{array}$ & \begin{tabular}{l|}
1 \\
2 \\
6
\end{tabular} & 8 & $\begin{array}{l}5 \\
1\end{array}$ & $\begin{array}{l}1 \\
5 \\
5\end{array}$ & $\begin{array}{l}2 \\
0\end{array}$ & $\begin{array}{l}4 \\
3\end{array}$ \\
\hline $\begin{array}{l}1 \\
1\end{array}$ & $\begin{array}{l}1 \\
8\end{array}$ & $\begin{array}{l}3 \\
0\end{array}$ & $\begin{array}{l}4 \\
0\end{array}$ & 8 & $\begin{array}{l}5 \\
1\end{array}$ & $\begin{array}{l}6 \\
9\end{array}$ & 8 & $\begin{array}{l}5 \\
1\end{array}$ & \begin{tabular}{|l}
9 \\
8
\end{tabular} & $\begin{array}{l}1 \\
5\end{array}$ & $\begin{array}{l}2 \\
8\end{array}$ & $\begin{array}{l}1 \\
2 \\
7\end{array}$ & 8 & $\begin{array}{l}5 \\
8\end{array}$ & $\begin{array}{l}1 \\
5 \\
6\end{array}$ & $\begin{array}{l}1 \\
3\end{array}$ & $\begin{array}{l}6 \\
5\end{array}$ \\
\hline $\begin{array}{l}1 \\
2\end{array}$ & $\begin{array}{l}1 \\
8\end{array}$ & $\begin{array}{l}3 \\
4\end{array}$ & $\begin{array}{l}4 \\
1\end{array}$ & 8 & $\begin{array}{l}5 \\
1\end{array}$ & $\begin{array}{l}7 \\
0\end{array}$ & 8 & $\begin{array}{l}5 \\
1\end{array}$ & \begin{tabular}{|l}
9 \\
9
\end{tabular} & $\begin{array}{l}1 \\
6\end{array}$ & $\begin{array}{l}5 \\
0\end{array}$ & $\begin{array}{l}1 \\
2 \\
8\end{array}$ & 8 & $\begin{array}{l}5 \\
1\end{array}$ & $\begin{array}{l}1 \\
5 \\
7\end{array}$ & $\begin{array}{l}1 \\
5\end{array}$ & $\begin{array}{l}3 \\
7\end{array}$ \\
\hline $\begin{array}{l}1 \\
3\end{array}$ & $\begin{array}{l}1 \\
8\end{array}$ & $\begin{array}{l}3 \\
0\end{array}$ & $\begin{array}{l}4 \\
2\end{array}$ & 8 & $\begin{array}{l}5 \\
1\end{array}$ & $\begin{array}{l}7 \\
1\end{array}$ & 8 & $\begin{array}{l}5 \\
1\end{array}$ & $\begin{array}{l}1 \\
0 \\
0\end{array}$ & $\begin{array}{l}1 \\
2\end{array}$ & $\begin{array}{l}4 \\
4\end{array}$ & \begin{tabular}{l|}
1 \\
2 \\
9
\end{tabular} & 8 & $\begin{array}{l}5 \\
1\end{array}$ & $\begin{array}{l}1 \\
5 \\
8\end{array}$ & $\begin{array}{l}2 \\
1\end{array}$ & $\begin{array}{l}4 \\
3\end{array}$ \\
\hline $\begin{array}{l}1 \\
4\end{array}$ & $\begin{array}{l}1 \\
8\end{array}$ & $\begin{array}{l}3 \\
0\end{array}$ & $\begin{array}{l}4 \\
3\end{array}$ & 8 & $\begin{array}{l}5 \\
1\end{array}$ & $\begin{array}{l}7 \\
2\end{array}$ & 8 & $\begin{array}{l}5 \\
1\end{array}$ & $\begin{array}{l}1 \\
0 \\
1\end{array}$ & $\begin{array}{l}1 \\
7\end{array}$ & $\begin{array}{l}2 \\
7\end{array}$ & $\begin{array}{l}1 \\
3 \\
0\end{array}$ & $\begin{array}{l}2 \\
5\end{array}$ & $\begin{array}{l}1 \\
7\end{array}$ & $\begin{array}{l}1 \\
5 \\
9\end{array}$ & 9 & $\begin{array}{l}2 \\
7\end{array}$ \\
\hline $\begin{array}{l}1 \\
5\end{array}$ & $\begin{array}{l}1 \\
8\end{array}$ & $\begin{array}{l}3 \\
0\end{array}$ & $\begin{array}{l}4 \\
4\end{array}$ & 8 & $\begin{array}{l}5 \\
1\end{array}$ & $\begin{array}{l}7 \\
3\end{array}$ & 8 & $\begin{array}{l}5 \\
1\end{array}$ & $\begin{array}{l}1 \\
0 \\
2\end{array}$ & 9 & $\begin{array}{l}5 \\
2\end{array}$ & \begin{tabular}{l|}
1 \\
3 \\
1
\end{tabular} & $\begin{array}{l}2 \\
2\end{array}$ & $\begin{array}{l}4 \\
9\end{array}$ & $\begin{array}{l}1 \\
6 \\
0\end{array}$ & $\begin{array}{l}1 \\
0\end{array}$ & $\begin{array}{l}4 \\
9\end{array}$ \\
\hline $\begin{array}{l}1 \\
6\end{array}$ & $\begin{array}{l}1 \\
8\end{array}$ & $\begin{array}{l}3 \\
1\end{array}$ & $\begin{array}{l}4 \\
5\end{array}$ & 8 & $\begin{array}{l}5 \\
1\end{array}$ & $\begin{array}{l}7 \\
4\end{array}$ & 8 & $\begin{array}{l}5 \\
1\end{array}$ & $\begin{array}{l}1 \\
0 \\
3\end{array}$ & $\begin{array}{l}1 \\
3\end{array}$ & $\begin{array}{l}5 \\
0\end{array}$ & $\begin{array}{l}1 \\
3 \\
2\end{array}$ & $\begin{array}{l}1 \\
9\end{array}$ & $\begin{array}{l}4 \\
6\end{array}$ & $\begin{array}{l}1 \\
6 \\
1\end{array}$ & $\begin{array}{l}1 \\
1\end{array}$ & $\begin{array}{l}3 \\
1\end{array}$ \\
\hline $\begin{array}{l}1 \\
7\end{array}$ & $\begin{array}{l}1 \\
8\end{array}$ & $\begin{array}{l}3 \\
0\end{array}$ & $\begin{array}{l}4 \\
6\end{array}$ & 8 & $\begin{array}{l}5 \\
1\end{array}$ & $\begin{array}{l}7 \\
5\end{array}$ & 8 & $\begin{array}{l}5 \\
1\end{array}$ & $\begin{array}{l}1 \\
0 \\
4\end{array}$ & $\begin{array}{l}2 \\
0\end{array}$ & $\begin{array}{l}5 \\
6\end{array}$ & $\begin{array}{l}1 \\
3 \\
3\end{array}$ & $\begin{array}{l}1 \\
8\end{array}$ & $\begin{array}{l}3 \\
4\end{array}$ & $\begin{array}{l}1 \\
6 \\
2\end{array}$ & 8 & $\begin{array}{l}4 \\
8\end{array}$ \\
\hline $\begin{array}{l}1 \\
8\end{array}$ & $\begin{array}{l}1 \\
8\end{array}$ & $\begin{array}{l}3 \\
0\end{array}$ & $\begin{array}{l}4 \\
7\end{array}$ & 8 & $\begin{array}{l}5 \\
1\end{array}$ & $\begin{array}{l}7 \\
6\end{array}$ & $\begin{array}{l}1 \\
7\end{array}$ & $\begin{array}{l}5 \\
3\end{array}$ & $\begin{array}{l}1 \\
0 \\
5\end{array}$ & $\begin{array}{l}1 \\
6\end{array}$ & $\begin{array}{l}4 \\
9\end{array}$ & \begin{tabular}{l|}
1 \\
3 \\
4
\end{tabular} & $\begin{array}{l}1 \\
8\end{array}$ & $\begin{array}{l}3 \\
4\end{array}$ & $\begin{array}{l}1 \\
6 \\
3\end{array}$ & 8 & $\begin{array}{l}5 \\
1\end{array}$ \\
\hline
\end{tabular}




\begin{tabular}{|c|c|c|c|c|c|c|c|c|c|c|c|c|c|c|c|c|c|}
\hline \begin{tabular}{l|}
1 \\
9
\end{tabular} & & $\begin{array}{l}33 \\
0\end{array}$ & $\begin{array}{l}4 \\
8\end{array}$ & 8 & $\begin{array}{l}5 \\
1\end{array}$ & $\begin{array}{l}7 \\
7\end{array}$ & $\begin{array}{l}1 \\
6\end{array}$ & $\begin{array}{l}4 \\
6\end{array}$ & $\begin{array}{l}1 \\
0 \\
6 \\
\end{array}$ & \begin{tabular}{|l}
1 \\
1
\end{tabular} & $\begin{array}{l}5 \\
1\end{array}$ & \begin{tabular}{l|}
1 \\
3 \\
5 \\
\end{tabular} & $\begin{array}{l}1 \\
4\end{array}$ & $\begin{array}{l}2 \\
9\end{array}$ & $\begin{array}{l}1 \\
6 \\
4\end{array}$ & 8 & \begin{tabular}{|l}
3 \\
0
\end{tabular} \\
\hline $\begin{array}{l}2 \\
0\end{array}$ & $\begin{array}{l}1 \\
8\end{array}$ & $\begin{array}{l}3 \\
0\end{array}$ & $\begin{array}{l}4 \\
9\end{array}$ & 8 & $\begin{array}{l}5 \\
1\end{array}$ & $\begin{array}{l}7 \\
8\end{array}$ & $\begin{array}{l}1 \\
6\end{array}$ & $\begin{array}{l}5 \\
3\end{array}$ & $\begin{array}{l}1 \\
0 \\
7\end{array}$ & \begin{tabular}{|l|}
1 \\
6
\end{tabular} & $\begin{array}{l}4 \\
6\end{array}$ & $\begin{array}{l}1 \\
3 \\
6 \\
\end{array}$ & $\begin{array}{l}1 \\
5\end{array}$ & $\begin{array}{l}4 \\
5\end{array}$ & $\begin{array}{l}1 \\
6 \\
5\end{array}$ & 9 & $\begin{array}{l}3 \\
0\end{array}$ \\
\hline $\begin{array}{l}2 \\
1\end{array}$ & $\begin{array}{l}1 \\
8\end{array}$ & $\begin{array}{l}2 \\
7\end{array}$ & $\begin{array}{l}5 \\
0\end{array}$ & 8 & $\begin{array}{l}5 \\
1\end{array}$ & $\begin{array}{l}7 \\
9\end{array}$ & 8 & $\begin{array}{l}5 \\
1\end{array}$ & $\begin{array}{l}1 \\
0 \\
8\end{array}$ & 6 & $\begin{array}{l}5 \\
2\end{array}$ & $\begin{array}{l}1 \\
3 \\
7\end{array}$ & $\begin{array}{l}1 \\
8\end{array}$ & $\begin{array}{l}3 \\
1\end{array}$ & $\begin{array}{l}1 \\
6 \\
6\end{array}$ & $\begin{array}{l}1 \\
8\end{array}$ & $\begin{array}{l}3 \\
0\end{array}$ \\
\hline $\begin{array}{l}2 \\
2\end{array}$ & $\begin{array}{l}1 \\
8\end{array}$ & $\begin{array}{l}3 \\
0\end{array}$ & $\begin{array}{l}5 \\
1\end{array}$ & 8 & $\begin{array}{l}5 \\
1\end{array}$ & $\begin{array}{l}8 \\
0\end{array}$ & 8 & $\begin{array}{l}5 \\
1\end{array}$ & $\begin{array}{l}1 \\
0 \\
9\end{array}$ & \begin{tabular}{|l|}
1 \\
3
\end{tabular} & $\begin{array}{l}5 \\
1\end{array}$ & $\begin{array}{l}1 \\
3 \\
8\end{array}$ & $\begin{array}{l}1 \\
1\end{array}$ & $\begin{array}{l}5 \\
5\end{array}$ & $\begin{array}{l}1 \\
6 \\
7\end{array}$ & 8 & $\begin{array}{l}5 \\
1\end{array}$ \\
\hline $\begin{array}{l}2 \\
3\end{array}$ & 8 & $\begin{array}{l}5 \\
2\end{array}$ & $\begin{array}{l}5 \\
2\end{array}$ & 8 & $\begin{array}{l}5 \\
1\end{array}$ & $\begin{array}{l}8 \\
1\end{array}$ & 8 & $\begin{array}{l}5 \\
1\end{array}$ & $\begin{array}{l}1 \\
1 \\
0\end{array}$ & \begin{tabular}{|l|}
1 \\
5
\end{tabular} & $\begin{array}{l}5 \\
0\end{array}$ & \begin{tabular}{l|}
1 \\
3 \\
9
\end{tabular} & $\begin{array}{l}1 \\
9\end{array}$ & $\begin{array}{l}5 \\
5\end{array}$ & $\begin{array}{l}1 \\
6 \\
8\end{array}$ & 8 & \begin{tabular}{|l|}
5 \\
1
\end{tabular} \\
\hline $\begin{array}{l}2 \\
4\end{array}$ & 8 & $\begin{array}{l}5 \\
1\end{array}$ & $\begin{array}{l}5 \\
3\end{array}$ & 8 & $\begin{array}{l}5 \\
1\end{array}$ & $\begin{array}{l}8 \\
2\end{array}$ & 8 & $\begin{array}{l}5 \\
1\end{array}$ & $\begin{array}{l}1 \\
1 \\
1\end{array}$ & \begin{tabular}{|l|}
1 \\
7
\end{tabular} & $\begin{array}{l}3 \\
9\end{array}$ & $\begin{array}{l}1 \\
4 \\
0\end{array}$ & $\begin{array}{l}2 \\
0\end{array}$ & $\begin{array}{l}3 \\
8\end{array}$ & $\begin{array}{l}1 \\
6 \\
9\end{array}$ & 8 & \begin{tabular}{|l|}
5 \\
1
\end{tabular} \\
\hline $\begin{array}{l}2 \\
5\end{array}$ & 8 & $\begin{array}{l}5 \\
1\end{array}$ & $\begin{array}{l}5 \\
4\end{array}$ & 8 & $\begin{array}{l}5 \\
1\end{array}$ & $\begin{array}{l}8 \\
3\end{array}$ & 8 & $\begin{array}{l}5 \\
1\end{array}$ & $\begin{array}{l}1 \\
1 \\
2\end{array}$ & \begin{tabular}{|l|}
1 \\
0
\end{tabular} & $\begin{array}{l}3 \\
9\end{array}$ & $\begin{array}{l}1 \\
4 \\
1\end{array}$ & $\begin{array}{l}1 \\
4\end{array}$ & $\begin{array}{l}4 \\
5\end{array}$ & & & \\
\hline $\begin{array}{l}2 \\
6\end{array}$ & 8 & $\begin{array}{l}5 \\
1\end{array}$ & $\begin{array}{l}5 \\
5\end{array}$ & 8 & $\begin{array}{l}5 \\
1\end{array}$ & $\begin{array}{l}8 \\
4\end{array}$ & 8 & $\begin{array}{l}5 \\
1\end{array}$ & $\begin{array}{l}1 \\
1 \\
3\end{array}$ & 7 & $\begin{array}{l}4 \\
1\end{array}$ & $\begin{array}{l}1 \\
4 \\
2\end{array}$ & $\begin{array}{l}1 \\
4\end{array}$ & $\begin{array}{l}4 \\
5\end{array}$ & & & \\
\hline $\begin{array}{l}2 \\
7\end{array}$ & 8 & $\begin{array}{l}5 \\
1\end{array}$ & $\begin{array}{l}5 \\
6\end{array}$ & 8 & $\begin{array}{l}5 \\
1\end{array}$ & $\begin{array}{l}8 \\
5\end{array}$ & 8 & $\begin{array}{l}5 \\
1\end{array}$ & $\begin{array}{l}1 \\
1 \\
4\end{array}$ & \begin{tabular}{|l|}
1 \\
6
\end{tabular} & $\begin{array}{l}5 \\
5\end{array}$ & $\begin{array}{l}1 \\
4 \\
3\end{array}$ & $\begin{array}{l}1 \\
6\end{array}$ & $\begin{array}{l}4 \\
7\end{array}$ & & & \\
\hline $\begin{array}{l}2 \\
8\end{array}$ & 8 & $\begin{array}{l}5 \\
1\end{array}$ & $\begin{array}{l}5 \\
7\end{array}$ & $\begin{array}{l}1 \\
7\end{array}$ & $\begin{array}{l}5 \\
6\end{array}$ & $\begin{array}{l}8 \\
6\end{array}$ & 7 & $\begin{array}{l}5 \\
7\end{array}$ & $\begin{array}{l}1 \\
1 \\
5\end{array}$ & \begin{tabular}{|l|}
1 \\
0
\end{tabular} & $\begin{array}{l}6 \\
0\end{array}$ & $\begin{array}{l}1 \\
4 \\
4\end{array}$ & $\begin{array}{l}1 \\
7\end{array}$ & $\begin{array}{l}3 \\
4\end{array}$ & & & \\
\hline $\begin{array}{l}2 \\
9\end{array}$ & & $\begin{array}{l}5 \\
0\end{array}$ & $\begin{array}{l}5 \\
8\end{array}$ & $\begin{array}{l}1 \\
6\end{array}$ & $\begin{array}{l}5 \\
3\end{array}$ & $\begin{array}{l}8 \\
7\end{array}$ & $\begin{array}{l}1 \\
0\end{array}$ & $\begin{array}{l}4 \\
0\end{array}$ & $\begin{array}{l}1 \\
1 \\
6\end{array}$ & 8 & $\begin{array}{l}3 \\
9\end{array}$ & $\begin{array}{l}1 \\
4 \\
5\end{array}$ & $\begin{array}{l}1 \\
0\end{array}$ & $\begin{array}{l}5 \\
2\end{array}$ & & & \\
\hline
\end{tabular}

Source: Field Data (2017)

$\mathrm{X}=$ Students discipline

$\mathrm{Y}=$ Parents' commitment to Child's Education

Table 3

Correlation Between Parents' Commitment to Child's Education and Students Discipline

\begin{tabular}{|l|l|l|}
\hline & $\mathrm{R}$ & $\mathrm{P}$ \\
\hline Pearson Coefficient & .387 & .000 \\
\hline No of Valid Cases & 169 & \\
\hline
\end{tabular}

Source: Field Data (2017)

Table 3 shows that there was a significant positive relationship between parents' commitment to child's education and students' discipline $(\mathrm{r}=.387, \mathrm{p}=.000)$. Therefore, the null hypothesis that there was no significant relationship between parents' commitment to child's education and students' discipline was rejected at .05 level of confidence. It can, therefore, be concluded that parents' commitment to child's education influences students' discipline in schools.

The findings in this study are supported by that of Mwikali (2005) who found that schools that have involved teacher-parents relationship and school-home consistency in expectations of behaviour for the students have been observed to lead to less indiscipline problems. She further states that such parents hold discussions with children which should therefore be facilitated by the school as often as possible as they inculcate a sense of concern and involvement in the parents and their children hence discipline. Besides avoiding parental responsibilities, parents also contribute to students' discipline by being bad role models (Mwikali, 2005). According to Otton (2001) there are signs that the most effective forms of parental involvement are those where parents' work directly with their children. Programs that show the most 
effective results include tutoring, working on homework with children, and reading with children. These active forms of parental involvement have had a greater impact on achievement than passive forms of involvement.

According to the Department of Education (2004) in the United States, studies have shown that students with involved parents are more likely to earn higher grades, pass their class and be promoted, they are more likely to attend school regularly and graduate and go on to postsecondary education, irrespective of their socio-economic status. Trusty (cited in Henderson \& Mapp, 2002) concurs with this, and claims that the level of parental involvement in high school influences the students' expectations to finish college. In addition, Obeidat and Al-Hassan (2009) maintain that not only do children with involved parents gain academically, but they are also more likely to show improved behaviour and to have better social skills.

\section{Summary Of The Findings Of The Study}

Parents commitment to children's education had a significant relationship with student indiscipline in schools $(\mathrm{r}=.387, \mathrm{p}=.000)$. Hence the null hypothesis was therefore rejected at .05 level of significance.

\section{Conclusions}

From the findings of the study, it was clear that parents' commitment to children's education had statistically significant influence on students' indiscipline. It can therefore be concluded that the higher the level of parents commitment to children's education, the less the level of indiscipline in schools.

\section{Recommendations}

The study recommends that parents should be more committed to their children's' education. This can be achieved through participating in school meetings and materially supporting the education of their children.

\section{References}

[1] Baumrind, D. (1966). Current patterns of parental authority. Developmental Psychology, 4(1), 1-103.

[2] Charles, L. (1995). Drug behaviour and modern society ( $2^{\text {nd }}$ Edition). Boston: Edward and Arnold.

[3] Darling., \& Steinberg, L. (1993). Parenting style as context: An integrative model. Psychological Bulletin, 113 (3), 487-496.

[4] Deepshika., \& Bhanot, S. (2011). Role of family environment on socio-emotional adjustment of adolescent girls in rural areas of eastern Uttar Pradesh. Journal of Psychology, Vol 2 (1), 53 - 56.

[5] Englund, M., Luckner, A., Whaley, G., \& Egeland, B. (2004). Children's achievement in early elementary school: Longitudinal effects of parental involvement, expectations and quality of assistance. Journal of Educational Psychology, Vol 94(4), 723-730.

[6] Eshiwani, G. (1993) .Education in Kenya since independence. Nairobi: Education Publishers.

[7] Etizi, M. (2008). Effective student discipline: Methods for teachers. Nairobi: Shrend Publishers.

[8] Greene, R. W. (2011). Behavior in school. Phi Delta Kappa, Vol. 26, 25-29.

[9] Griffin, G. (1994). School mastery: Straight talk about boarding schools management in Kenya. Nairobi: Lectern Publication Ltd.

[10] Henderson, A. T. \& Mapp, K. L. (2002). A new wave of evidence: The impact of school, family, and community connections on student achievement. Texas, USA, Southwest Educational Development Laboratory.

[11] Hussain, S., \& Munaf, S. (2012). Perceived father acceptance-rejection in childhood and psychological adjustment in adulthood. International Journal of Business and Social Science. Vol $3(1), 149-156$.

[12] Imber, M \& W. A. Neidt. (1990) Teacher participation in school decision making. Newsbury Park: Sage Publication Inc.

[13] Kabiru, L.K. (2006). A Study of Factors that Contributes to unrest in Secondary Schools in Kirinyaga District. (Unpublished M.Ed Research Project), Kenya, Kenyatta University.

[14] Keith, T. Z. \& Keith, P. B. (1993). Does parental involvement affect eighth-grade student achievement? Structural analysis of national data. School Psychology Review, Vol. 22, 474-496. 
[15] Khalid, S. (2004). Development and validation of the index of personal growth and the familial and dispositional predictors of personal growth (Unpublished $\mathrm{PhD}$ Thesis). National Institute of Psychology and centre of Excelance. Islamabad, Quaid-e- Azam University.

[16] Krejice, R.\& Morgan, D. (1970). Determining sample sizes of research activities. Education and Psychological Measurement, Vol. 30, 607-610.

[17] Larocque, M., Kleiman, I., \& Darling, S. (2011). Parental involvement: The missing link in school achievement. Preventing School Failure, Vol 55(3), 115-122.

[18] Lockheed, M.(1991) .Improving education. Education Review. Vol 16 (3)303-311.

[19] Masese, A (2007).A Study of the causes of Drug Abuse Among students in selected Secondary schools in Kisumu Municipality,Kenya.( Unpublished master's thesis) Kenya, University of Nairobi.

[20] MOEST (2014). Basic Education Statistical Booklet. Nairobi, UNICEF.

[21] Muchemi, N. C. (2006). Management of Student Riots in public secondary schools in Meru South District, (Unpublished Med Thesis) Nairobi, Kenyatta University.

[22] Muchemi, W. (2005). Education the living bud of a nation's development. Daily Nation,p23. June 22.

[23] Mwikali, S. (2005) .Factors influencing school strikes in central division- Machakosdistrict. (Unpublished master's thesis). Nairobi, Kenyatta University.

[24] Obeidat, O. M. and Al-Hassan, S. M. (2009). School-parent-community partnerships: The experience of teachers who received the queen Rania award for excellence in education in the Hashemite Kingdom of Jordan. The School Community Journal, Vol. 19(1), 119-136.

[25] Osher, D., Bear, G. G., Sprague, J. R., \& Doyle, W. (2010). How can we improve school discipline? Educational Researcher, Vol. 39(1), 48-58.

[26] Quilliams, L \& Beran, T. (2009). Children at risk for academic failure: A model of individual and family factors. Exceptionality Education International, Vol. 19(2), 63-76.

[27] Republic of Kenya. (2012). Sessional Paper No. 14 of 2012 on realigning Education and Training to the Constitution of Kenya 2010 and Vision 2030 and beyond. Ministry of Education and Ministry of Higher Education, Science and Technology. Nairobi: Government Printers.

[28] Sanders, M. G. \& Sheldon, S. B. (2009). Principals matter: A guide to school, family, and community partnerships. Corwin: A SAGE Company.

[29] Sirvani, H. (2007). The effect of teacher communication with parents on students' mathematics achievement. American Secondary Education, VOl. 36(1), 31-46.

[30] Suizzo, M., Jackson, K. M., Pahlke, E., Marroquin, Y., Blondeau, L., \& Martinez, A. (2012). Pathways to achievement: How low-income Mexican-origin parents promote their adolescents through school. Family Relations, Vol. 61. 533-547. 